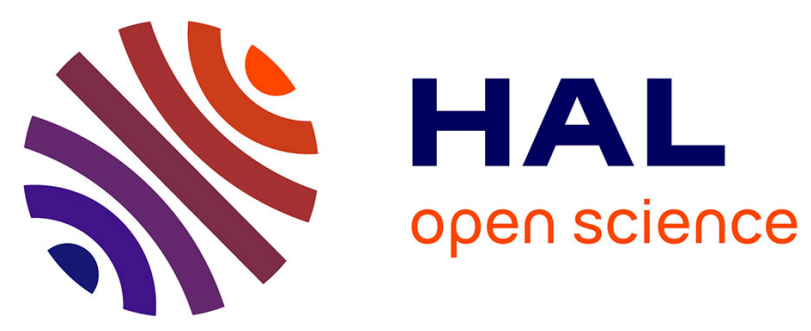

\title{
Mosquitoes and malaria transmission in irrigated rice-fields in the Benoue valley of northern Cameroon
}

Vincent Robert, A van den Broek, P Stevens, R Slootweg, V Petrarca, Mario Coluzzi, Gilbert Le Goff, M A Di Deco, Pierre Carnevale

\section{- To cite this version:}

Vincent Robert, A van den Broek, P Stevens, R Slootweg, V Petrarca, et al.. Mosquitoes and malaria transmission in irrigated rice-fields in the Benoue valley of northern Cameroon. Acta Tropica, 1992, 52 (2-3), pp.201-204. 10.1016/0001-706x(92)90036-w . hal-03363311

\section{HAL Id: hal-03363311 https://hal.science/hal-03363311}

Submitted on 3 Oct 2021

HAL is a multi-disciplinary open access archive for the deposit and dissemination of scientific research documents, whether they are published or not. The documents may come from teaching and research institutions in France or abroad, or from public or private research centers.
L'archive ouverte pluridisciplinaire HAL, est destinée au dépôt et à la diffusion de documents scientifiques de niveau recherche, publiés ou non, émanant des établissements d'enseignement et de recherche français ou étrangers, des laboratoires publics ou privés. 


\title{
Mosquitoes and malaria transmission in irrigated rice-fields in the Benoue valley of northern Cameroon
}

\author{
V. $/$ Robert $^{\mathrm{a}}$, A. van den Broek ${ }^{\mathrm{b}}$, P. Stevens ${ }^{\mathrm{b}}$, R. Slootweg ${ }^{\mathrm{c}}$, \\ V. Petrarca ${ }^{d}$, M. Coluzzi ${ }^{d}$, G. Le Goff ${ }^{\mathrm{a}}$, M.A. Di Deco ${ }^{d}$ and \\ P./Carnevale ${ }^{\mathbf{a}}$ \\ ${ }^{2}$ ORSTOM and OCEAC, Yaounde, Cameroon, ${ }^{\mathrm{b}}$ Project CIBP/MEAVSB, Garoua, Cameroon, "Centre for \\ Environmental Studies, Leiden. Netherlands, and ${ }^{\mathrm{d}}$ Istituto di Parassitologia, Università di Roma, Rome, \\ Italy
}

(Received 14 April 1992; accepted 4 August 1992)

Key words: Anopheles arabiensis; Rice-field; Malaria transmission; Cameroon

Africa has a very high human population growth rate which is not matched by the rate of increase in agricultural production per capita. One solution often envisaged is to increase of the area of irrigated land, permitting two crops per year. The most extensively irrigated crop is rice, for which demand continues to increase. Rice-fields are usually flooded for long periods, providing suitable breeding places for mosquitoes. Everywhere in tropical Africa, rice-growing areas allow considerable multiplication of malaria vectors of the Anopheles gambiae complex (Service, 1989; Lacey and Lacey, 1990).

$\because$ In the North Province of Cameroon, it has been well established that the largescale irrigation development following the Lagdo dam has resulted in increasing human malaria incidence (Slootweg and Schooten, 1990). This note describes a preliminary entomological study carried in 1990 in the village of Gounougou.

Gounougou is located $40 \mathrm{~km}$ south-east of Garoua on the right bank of the Benoue river, immediately downstream of the Lagdo barrage. The region belongs to Sudan savanna zone, having a distinct rainy season from May to October with a total annual rainfall of $1000 \mathrm{~mm}$. In the dry season (November-April) rainfall is very rare. The majority of the immigrant population of Gounougou settled between 1978 and 1985, during the construction of the Lagdo dam and the subsequent irrigation scheme. Irrigated rice-culture commenced in 1987 over 50 ha; in 1988 another 30 ha of rice and 80 ha of a variety of crops was added. At present some 800 ha for rice and other crops are under grading around the nearby villages of

Correspondence to: V. Robert, Antenne ORSTOM of OCEAC, B.P. 288, Yaounde, Cameroon. 
Ouro-Doukoudje and Bessoum. The main irrigation canal receives its water from the Lagdo reservoir. Each year two crops are grown, seldom with the use of insecticide. The village of Gounougou has a multi-ethnic population of approximately 2300 , consisting mainly of farmers and their families. The use of mosquitonets or mosquito-coil is frequent but not universal. Lifestock (cows, sheep, goats, pigs, poultry) are numerous and are found in the compounds during the day as well as at night.

Rice-fields are very productive for mosquito larvae: in July and August, after transplantation of the rice-seedlings, only $A$. gambiae s.l. was observed, but in the second half of September, when rice was maturing and during harvest, there were also A. rufipes, An. coustani and A. welcomei. This successsion of species associated with the growth of the rice is consistent with previous observations in Kenya (Chandler and Highton, 1975) and Burkina Faso (Robert et al., 1988).

Pyrethrum spray catches in the late afternoon revealed that adults of the $A$. gambiae complex represented more than $90 \%$ of the indoor resting mosquitoes. Cytogenetic analysis of half gravid females of $A$. gambiae s.l. showed that catches consisted only of An. arabiensis during the dry season (in February $n=85$ ) as well as during the rainy season (in September $n=22$ ). Even though the sample sizes were not very important, there is probably no An. gambiae s.s. in the rice-fields, otherwise the collection technique used would have evidenced it. In the savannas of West Africa the dominant species in semi-permanent breeding places (e.g., rice-fields) is A: gambiae, especially where the Mopti cytotype occurs (Coluzzi et al., 1985; Robert et al., 1989). The general climatic conditions are similar in Mali/Burkina Faso and Northern Cameroon, but the main entomological difference is the absence of A. gambiae Mopti in our study area in North Cameroon. Where the Mopti cytotype is absent $A$. arabiensis has an advantage in the occupation of such extensive habitats under permanent irrigation. This observation is consistent with the situation in East Africa as described by Coosemans et al. (1989) for Burundi and by ljumba et al. (1990) for Kenya.

The northern Cameroon A. arabiensis showed a high degree of inversion polymorphism, as in previous observations for other sudan savanna areas of West Africa. $A$. arabiensis was polymorphic for the inversion systems $2 \mathrm{R} a, 2 \mathrm{R} b, 2 \mathrm{R} d$ and $3 \mathrm{R} a$ (Table 1). The observed karyotype frequencies were in agreement with the HardyWeinberg equilibrium, except for the inversion system $2 \mathrm{R} a$, which showed a significant deficiency of heterozygotes. Moreover, significantly lower frequencies of the $2 \mathrm{R} b$ and $2 \mathrm{R} b c$ arrangements were observed in the rainy season than in the dry season:

The source of the blood meals taken by An. gambiae s.l. (very probably $A n$.

\section{TABLE 1}

Frequencies of alternative arrangements of $2 \mathrm{R}$ and $3 \mathrm{R}$ chromosomes in samples of Anopheles arabiensis females obtained in the village of Gounougou, North Cameroon, during 1990

\begin{tabular}{|c|c|c|c|c|c|c|c|c|c|c|c|}
\hline \multirow{2}{*}{$\begin{array}{l}\text { Inversion system: } \\
\text { Alternative arrangement: }\end{array}$} & \multicolumn{2}{|l|}{$2 \mathrm{R} a$} & \multicolumn{4}{|l|}{$2 \mathrm{R} b$} & \multicolumn{3}{|l|}{$2 \mathrm{R} d$} & \multicolumn{2}{|l|}{$3 \mathrm{R} a$} \\
\hline & $+^{a}$ & $a$ & $+b$ & $b$ & $b c$ & $b e$ & $+^{d}$ & $d$ & be & $++^{a}$ & $a$ \\
\hline$\%$ & 72.4 & 27.6 & 13.3 & 51.0 & 34.7 & 1.0 & 79.6 & 19.4 & 1.0 & 76.5 & 23.5 \\
\hline
\end{tabular}


arabiensis) from different resting places was analysed using a dot-ELISA on a dipstick (Savage et al., 1991). Human blood was found in 1 out of 19 mosquito midguts in February, 10 out of 30 in May-June and 36 out of 48 in September-October. The presence of numerous mosquitoes containing nonhuman blood inside houses where cattle were not kept provides evidence for indoor resting after feeding on cattle outside.

During the rainy season, from mid-July to mid-September, outdoor human bait catches from 1800 to $2000 \mathrm{~h}$ and indoor human bait catches from 2000 to $0600 \mathrm{~h}$ were performed at 6 houses distributed evenly within the village. The total collection effort for 4 outdoor catches was 12 man-evenings and for 11 indoor catches was 33 man-nights. The total number of mosquitoes caught was $1801,80 \%$ being anophelines and $20 \%$ culicines (Table 2). During the night $82 \%$ of the indoors mosquitoes were anophelines, but this proportion among the outdoor collections in the evenings was only $41 \%$. The Anopheles species were: A. gambiae s.1. (68\%), A. funestus $(25 \%)$ and $A$. pharoensis $(7 \%)$.

The average biting rate was 83.7 bites per man per night, consisting of 31.6 A. gambiae s.l., $10.6 \mathrm{~A}$. funestus, $13.0 \mathrm{~A}$. pharoensis and 28.5 culicines. The peak biting hour was around midnight for $A$. gambiae s.l., around $04 \mathrm{~h}$ for $A$. funestus and between 18 and $19 \mathrm{~h}$ for $A$. pharoensis.

The-sporozoite index for night-biting collections indoors was $1.2 \%$ for $A$. gambiae s.1., $1.3 \%$ for $A$. funestus and $2.1 \%$ for $A$. pharoensis. The finding of $A$. pharoensis as a malaria vector agrees with the observations of Carrara et al. (1990) and of ljumba et al. (1990).

The malarial inoculation rate was estimated for all anophelines at 0.82 infective bites per man per night, that is to say, each person who does not take any precautionary measures would receive 49 infective bites in the 60 days from mid-July to midSeptember.

In these rice-fields the anopheline density is high, but its anthropophilic biting fraction is short-lived (Table 2). For night catches indoors only, the parous rate was $38 \%$ for $A$. gambiae s.1., $46 \%$ for $A$. funestus and $30 \%$ for $A$. pharoensis. These data indicate daily survival rates of $0.68,0.79$ and 0.62 , respectively.

Similar observations associating a high density with a relative young population

TABLE 2

Numbers of mosquito-bitting collected and numbers of dissected in the village of Gounougou, North Cameroon, from mid-July to mid-September 1990

\begin{tabular}{|c|c|c|c|c|c|c|}
\hline Hours & Collection & Species & $\begin{array}{l}\text { A. gambiae s.l. } \\
\text { (A. arabiensis?) }\end{array}$ & A. funestus & A. pharoensis & Culicine \\
\hline $\begin{array}{l}18.00 \\
\text { to } \\
20.00\end{array}$ & $\begin{array}{l}12 \text { man-evenings, } \\
\text { outdoors }\end{array}$ & $\begin{array}{c}\text { mosquitoes } \\
\text { ovaries } \\
\text { parous }\end{array}$ & $\begin{array}{l}9 \\
9 \\
0\end{array}$ & 0 & $\begin{array}{r}45 \\
22 \\
7\end{array}$ & 78 \\
\hline $\begin{array}{l}20.00 \\
\text { to } \\
06.00\end{array}$ & $\begin{array}{l}33 \text { man-nights, } \\
\text { indoors }\end{array}$ & $\begin{array}{l}\text { mosquitoes } \\
\text { ovaries } \\
\text { parous } \\
\text { salivary glands } \\
\text { sporozoite }\end{array}$ & $\begin{array}{r}966 \\
736 \\
279 \\
470 \\
6\end{array}$ & $\begin{array}{r}351 \\
224 \\
104 \\
227 \\
3\end{array}$ & $\begin{array}{r}56 \\
47 \\
14 \\
47 \\
1\end{array}$ & 296 \\
\hline
\end{tabular}


were previously made in Burundi (Coosemans, 1989) and in Burkina Faso (Robert et al., 1991a). Although various authors have highlighted the importance of this phenomenon, which limits malaria transmission, up to now it has not been fully explained (Robert et al., 1991b).

\section{References}

Chandler J.A., Highton R.B. (1975) The succession of mosquito species in rice fields in Kisumu area of Kenya, and their possible control. Bull. Ent. Res. 65, 295-302.

Carrara G.C., Petrarca V., Niang M., Coluzzi M. (1990) Anopheles pharoensis and transmission of Plasmodium falciparum in the Senegal River delta, West Africa. Med. Vet. Entomol. 4, 421-424.

Coluzzi M., Petrarca V., Di Deco M.A. (1985) Chromosomal inversion intergradation and incipient speciation in Anopheles gambiae. Boll. Zool. 52, 45-63.

Coosemans M. (1989) Recherche épidémiologique dans un foyer de paludisme peu stable en Afrique centrale. Académie royale des sciences d'outre-mer (Bruxelles), 22, 3, 1-62.

Coosemans M., Petrarca V., Barutwanayo M., Coluzzi M. (1989) Species of the Anopheles gambiae complex and chromosomal polymorphism in a rice-growing area of the Rusizi Valley, Burundi. Parassitologia 31, 113-122.

Ijumba J.N., Mwangi R.W., Bëier J.C. (1990) Malaria transmission potential of Anopheles mosquitoes in the Mwea-Tbere irrigation scheme, Kenya. Med. Vet. Entomol. 4, 425-432.

Lacey L.A., Lacey C.M. (1990) The medical importance of riceland mosquitoes and their control using alternatives to chemical insecticides. J. Am. Mosq. Cont. Ass. 6, suppl.2, 1-93.

Robert V., Ouari B., Ouedraogo V., Carnevale P. (1988) Etude écologique des Culicidae adultes et larvaires dans une rizière en Vallee du Kou, Burkina Faso. Acta Trop. 45, 351-359.

Robert V., Petrarca V., Carnevale P., Ovazza L., Coluzzi M. (1989) Analyse cytogénétique du complexe Anopheles gambiae dans la région de Bobo-Dioulasso (Burkina Faso). Ann. Parasit. Hum. Comp. 64, 290-311.

Robert V., Ouedraogo V., Carnevale P. (1991a) La transmission du paludisme humain dans un village de la vallée du Kou, Burkina Faso. In Le paludisme en Afrique de l'Ouest. Paris, ORSTOM éd., collection Etudes et Thèses, 5-15.

Robert V., Petrarca V., Coluzzi M., Boudin C., Carnevale P. (1991b) Etude des taux de parturité et d'infection du complexe Anopheles gambiae dans la rizière de la vallée du Kou, Burkina Faso. In Le paludisme en Afrique de l'Ouest. Paris, ORSTOM éd., collection Etudes et Thèses, 17-35.

Savage H.M., Duncan J.F., Roberts D.R., Shold L.L. (1991) A dipstick ELISA for rapid detection of human blood meals in mosquitoes. J. Am. Mosq. Contr. Ass. 7, 16-23.

Service M.W. (1989) Irrigation: boon or bane? Service MW ed. Demography and Vector-Borne Diseases. Boca Raton, FL: CRC Press, pp. 283-301.

Slootweg R. and Van Schooten M.L.F. (1990) Paludisme et irrigation; augmentation du paludisme à cause de l'introduction des cultures irriguées à Gounougou et estimation de la perte au niveau du ménage. Mission d'étude et d'aménagement de la vallée supérieure de la Bénoué, Rapport du projet pisciculture $n^{\circ} 36$, Garoua, Cameroun. 